\title{
Genomic organization of the entomopathogenic bacterium Bacillus thuringiensis subsp. berliner 1715
}

\author{
Cathrine Rein Carlson, ${ }^{1}$ Trine Johansen, ${ }^{1}$ Marguerite-M. Lecadet ${ }^{2}$ and \\ Anne-Brit Kolstø ${ }^{1}$
}

Author for correspondence: Anne-Brit Kolstø. Tel: +47 22958460. Fax: + 4722694130.
e-mail: a.b.kolsto@farmasi.uio.no

1 Institute of Pharmacy and Biotechnology Centre of Oslo, University of Oslo, PB 1125, 0316 Oslo, Norway

2 Bacteries

Entomopathogenes, Institut Pasteur, 28 rue du Dr Roux, 75724 Paris Cedex 15, France

\begin{abstract}
A physical and genetic map of the Bacillus thuringiensis subsp. berliner 1715 (serotype 1) chromosome was constructed by pulsed field gel electrophoresis using three restriction enzymes, Ascl, Notl and Sfil. A total of 24 restriction enzyme sites and 28 probes were located on the map. The chromosome size was $5.7 \mathrm{Mb}$. Consistent with previous mapping of Bacillus cereus chromosomes, the genes were nonrandomly distributed. Genes which are often plasmid-encoded were located on one half of the chromosome, whereas the other half contained rRNA genes and the origin region. Hybridization with macro-restriction fragments showed that the region containing rRNA genes and the origin was similar to that of the B. cereus type strain, ATCC 14579, and confirmed that the region was conserved between the B. cereus and $B$. thuringiensis chromosomes. The insecticidal toxin probe crylA or the transposon probe Tn 4430 hybridized to six extrachromosomal elements of 60 , $60,100,130,270$ and $600 \mathrm{~kb}$, indicating that the genome size was at least 6.9 Mb.
\end{abstract}

Keywords: Bacillus thuringiensis, physical mapping, transposon, insecticidal genes, pulsed field gel electrophoresis

\section{INTRODUCTION}

Bacillus thuringiensis is a spore-forming Gram-positive soil bacterium. During sporulation, a crystal containing an insecticidal protoxin is formed inside the cell. Because of its production of insecticidal toxins, $B$. thuringiensis is the most widely used source of biological pesticides (Aronson, 1993; Höfte \& Whiteley, 1989). At least 50 protoxins have been characterized by gene sequencing and toxicity profiles (Aronson, 1993). Four major classes of insecticidal protoxin genes have been proposed (cryI$I V)$ (Höfte \& Whiteley, 1989) and each class has been further divided into several subclasses (cryIA-cryID). Most toxins are active against larvae of lepidopteran species, but some show toxicity against dipteran or coleopteran species (Höfte \& Whiteley, 1989). The cry genes are usually located on large plasmids $(50 \mathrm{~kb}$ or larger) (Carlton \& Gonzales, 1985; Kronstad et al., 1983), although chromosomal $c r y$ genes have been reported in some B. thuringiensis strains (Carlson \& Kolstø, 1993; Klier et al., 1982; Kronstad et al., 1983). A transposon of the Tn 3 family (Tn4430) flanked by IS elements is often, but not always, present in the vicinity of the cry genes
(Lereclus et al., 1986; Mahillon et al., 1985; Menou et al., 1990).

The technique of pulsed field gel electrophoresis (PFGE) allows separation of megabase-sized linear DNA fragments (Schwartz \& Cantor, 1984; Smith et al., 1988) and is useful for the construction of physical maps of bacterial chromosomes (for a review, see Smith \& Condemine, 1990). Cloned genes may easily be located on these physical maps and thus a genetic map can be constructed. Circular DNA moves aberrantly by PFGE, or not at all, depending on size and topology (Beverley, 1988; Hightower \& Santi, 1989). We have previously used PFGE to construct a map of one $B$. thuringiensis chromosome of $5.4 \mathrm{Mb}$ (subsp. thuringiensis HD2; Carlson \& Kolstø, 1993). Bacillus cereus does not produce insecticidal protoxin crystals, but otherwise these bacteria cannot be distinguished from B. thuringiensis (Carlson et al., 1994; Gordon et al., 1973; Smith et al., 1952). The chromosome size of ten $B$. cereus strains have been determined, and chromosome maps constructed for six of them (Carlson et al., 1992; Carlson \& Kolstø, 1994; Kolstø et al., 1990). The chromosomes ranged in size from $2.4 \mathrm{Mb}$ to $6.3 \mathrm{Mb}$. A 
(a)

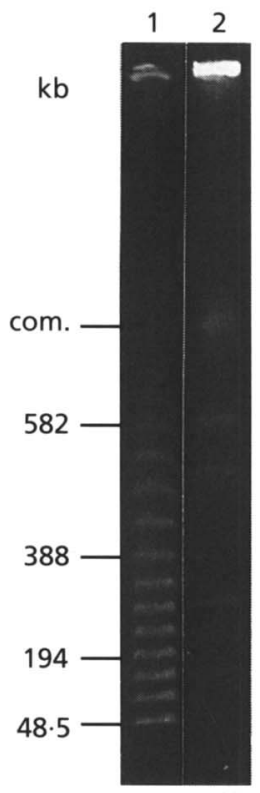

(b)

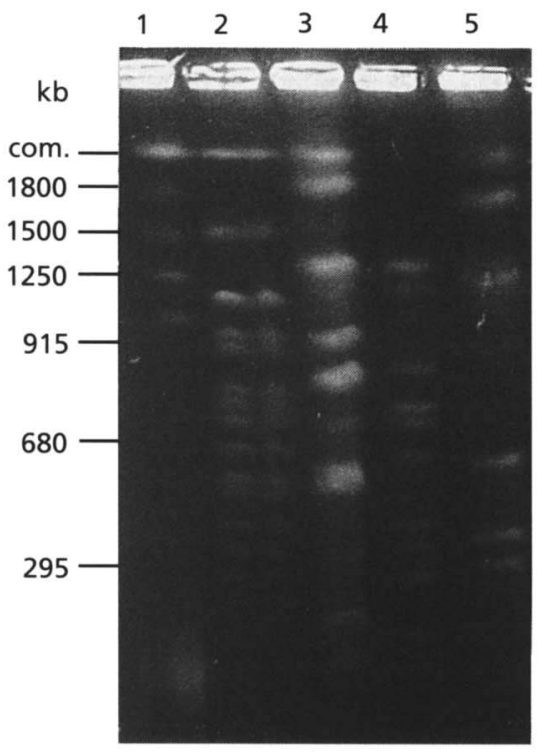

(c)

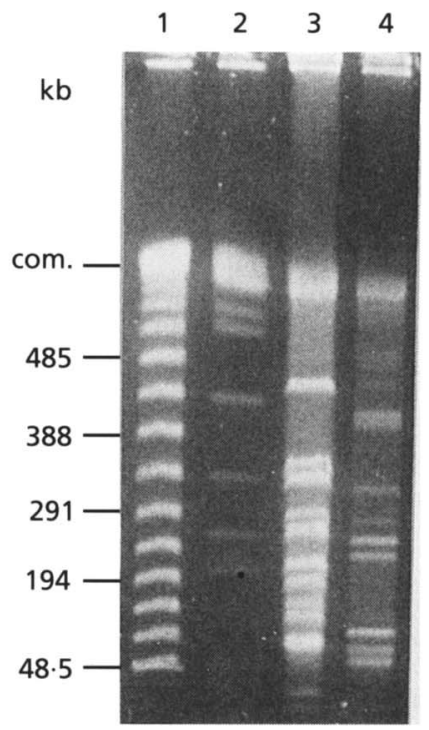

(d)

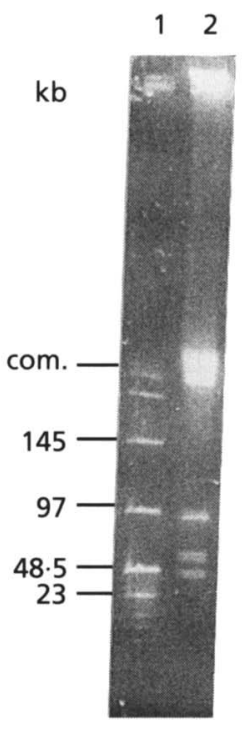

Fig. 1. PFGE of DNA from two $B$. thuringiensis strains. (a) Lanes: 1 , lambda concatemers (48.5-1018.5 kb, New England Biolabs); 2 , undigested $B$. thuringiensis subsp. berliner 1715 . Running conditions: $4 \mathrm{~s}$ for $10 \mathrm{~min}$ at $170 \mathrm{~mA}$, then $30 \mathrm{~s}$ pulses for $20 \mathrm{~h}$ at $150 \mathrm{~mA}, 15^{\circ} \mathrm{C}$ (Beckman). (b) Lanes: 1, MegaBase IV (size range 1.03-3.30 Mb, Gibco, BRL); 2, Saccharomyces cerevisiae (225-1900 kb, New England Biolabs); 3-5, B. thuringiensis subsp. berliner 1715 digested with Ascl (lane 3), Notl (lane 4), Sfil (lane 5). Running conditions: $100 \mathrm{~s}$ pulses for $20 \mathrm{~h}$ at $150 \mathrm{~mA}$ and $200 \mathrm{~s}$ pulses for $20 \mathrm{~h}$ at $150 \mathrm{~mA}, 15^{\circ} \mathrm{C}$ (CHEF Mapper, Bio-Rad Laboratories). The Ascl and Sfil digestions were digested for only $1 \mathrm{~h}$, resulting in two partial fragments of $230 \mathrm{~kb}$ (A6 and A7) and $770 \mathrm{~kb}$ (A5, A6 and A7) in the Ascl digests, and a weak fragment of $910 \mathrm{~kb}$ (S4 and S6) in the Sfil digest. The DNA in the compression region (com.) corresponds to partial fragments larger than $1850 \mathrm{~kb}$. A weak plasmid band of $270 \mathrm{~kb}$ was seen in all three digests (co-migrating with the $280 \mathrm{~kb}$ Sfil fragment in lane 5). (c) Lanes: 1, lambda concatemers; 2, S. cerevisiae; 3, B. thuringiensis subsp. thuringiensis HD2 digested with Notl; 4, B. thuringiensis subsp. berliner 1715 digested with Notl. Running conditions: as (a). (d) Lanes: 1, lambda concatemers and HindIII fragments of lambda (0.13-194 kb, New England Biolabs); 2, B. thuringiensis subsp. berliner 1715 digested with Notl. Running conditions: $4 \mathrm{~s}$ for $10 \mathrm{~min}$ at $170 \mathrm{~mA}$, then $6 \mathrm{~s}$ pulses for $20 \mathrm{~h}$ at $150 \mathrm{~mA}, 15^{\circ} \mathrm{C}$ (Beckman).

comparison of the maps showed a similar organization in one half of the chromosome harbouring the origin of replication, while the other half appeared to have greater variation and probes in this area may be present extrachromosomally in strains with a small chromosome (Carlson \& Kolstø, 1994). We report here a physical map of the $B$. thuringiensis subsp. berliner 1715 chromosome for three restriction enzymes and have assigned probes to the map. This strain has been widely used for research purposes, and its $\operatorname{cryI} A$ genes and IS elements have been cloned and sequenced.

\section{METHODS}

Bacterial strains. B. thuringiensis subsp. berliner 1715 was obtained from the International Entomopathogenic Bacillus Centre (IEBC Collection), Institut Pasteur, Paris. B. thuringiensis subsp. thuringiensis HD2 was obtained from the Bacillus Genetic Stock Center, Department of Biochemistry, The Ohio State University, Columbus. B. cereus type strain ATCC 14579 and B. cereus ATCC 10987 were obtained from the American Type Culture Collection (ATCC), Rockville, MD, USA.

Preparation, digestion and separation of DNA. Cells were grown overnight at $37^{\circ} \mathrm{C}$. They were then harvested and total
DNA was prepared in agarose blocks as previously described (Carlson \& Kolstø, 1993; Kolstø et al., 1990; Smith et al., 1988). The DNA was digested with $A s c I, N o t I$ and SfiI (New England Biolabs) and separated by Gene-line 1 (Beckman Instruments) or the CHEF Mapper or the CHEF Mapper XA System (BioRad Laboratories) (Carlson \& Kolstø, 1993, 1994).

Southern blotting and hybridization. DNA was blotted overnight onto nylon membranes (MSI) (Kolstø et al., 1990). Genomic DNA was hybridized with gene probes from B. cereus, $B$. thuringiensis and Bacillus subtilis. The references of these probes are given in Table 2 . B. cereus $(\mathrm{Bc})$ random probes were obtained from a $B$. cereus ATCC 10987 library in pUC18 prepared in our laboratory. When chromosomal fragments were used as probes, the fragments were separated in low-melting-point agarose (LMA) by PFGE: $25 \mu$ of a fivefold dilution of LMA containing the DNA was boiled, then the DNA labelled by using random priming and the Klenow enzyme (New England BioLabs) and ${ }^{32}$ P-labelled dCTP and dATP (Feinberg \& Vogelstein, 1983, 1984). The probe was incubated for $1 \mathrm{~h}$ at $37^{\circ} \mathrm{C}$ to complete the polymerase reaction. After incubation, the denaturated probe was added directly to the (pre)hybridization solution (Kolstø et al., 1990), containing denatured and fragmented salmon sperm DNA, without further cleaning. A temperature of $65^{\circ} \mathrm{C}$ was used for all hybridization and washing procedures, except for the $B$. subtilis probe pAK1 where a temperature of $55^{\circ} \mathrm{C}$ was used. 


\section{RESULTS AND DISCUSSION}

\section{Digestion of $B$. thuringiensis subsp. berliner 1715 genomic DNA with three restriction enzymes and chromosome size estimation}

Before digestion of the genomic DNA with restriction enzymes, the uncut DNA was analysed by PFGE. Several weak bands were observed (Fig. 1a). These extrachromosomal bands may originate from large linear plasmids, or circular plasmids that have been partially linearized during the preparation of the DNA as previously reported for Agrobacterium tumefaciens (AllardetServent et al., 1993) and Rbizobium meliloti (Sobral et al., 1991), or they might be smaller circular plasmids that migrate in a pulse-time-independent manner (Beverley, 1988; Hightower \& Santi, 1989).

The size of each restriction fragment generated by $A s c \mathrm{I}$, Not I and SfiI restriction enzymes was determined by using CHEF and Beckman separation systems. The restriction fragments obtained by digestion with the three enzymes were numbered as shown in Table 1 . The sizes of the fragments were determined from four gels at long pulse times separating fragments up to about $2 \mathrm{Mb}$ (Fig. $1 \mathrm{~b})$, and three gels at short pulse times separating

Table 1. Sizes of Ascl, Notl and Sfil restriction fragments and estimations of the size of the $B$. thuringiensis subsp. berliner 1715 chromosome

Sizes of fragments larger than $500 \mathrm{~kb}$ were determined using Saccharomyces cerevisiae chromosomes and MegaBase IV as standards. Phage lambda concatemers were used for fragments below $500 \mathrm{~kb}$.

\begin{tabular}{|c|c|c|c|c|c|}
\hline \multicolumn{2}{|c|}{$A s c I$} & \multicolumn{2}{|c|}{ NotI* } & \multicolumn{2}{|l|}{ SfiI } \\
\hline Fragment & $\begin{array}{l}\text { Size } \\
\text { (kb) }\end{array}$ & Fragment & $\begin{array}{l}\text { Size } \\
\text { (kb) }\end{array}$ & Fragment & $\begin{array}{l}\text { Size } \\
\text { (kb) }\end{array}$ \\
\hline A1 & 1790 & $\mathrm{~N} 1$ & 1460 & S1 & 1770 \\
\hline $\mathrm{A} 2$ & 1420 & N2 & 860 & S2 & 1410 \\
\hline A3 & 920 & N3 & 780 & S3 & 1280 \\
\hline A4 & 850 & $\mathrm{~N} 4$ & 750 & S4 & 630 \\
\hline A5 & 550 & N5 & 650 & S5 & 380 \\
\hline A6 & 160 & N6 & 450 & S6 & 280 \\
\hline \multirow[t]{4}{*}{ A7 } & 70 & N7 & $\begin{array}{c}330 \\
(300) \\
(270)\end{array}$ & & \\
\hline & & N8 & $\begin{array}{r}250 \\
(100) \\
(60)\end{array}$ & & \\
\hline & & N9 & 50 & & \\
\hline & & N10 & 50 & & \\
\hline \multicolumn{3}{|l|}{ Total } & 5630 & & 5750 \\
\hline
\end{tabular}

* At least four NotI fragments (in parentheses) originated from extrachromosomal DNA and are not included in the chromosome size estimation. The $100 \mathrm{~kb}$ and $60 \mathrm{~kb}$ NotI bands were doublets. fragments smaller than $500 \mathrm{~kb}$ (Fig. 1c). Sizes of the double-digested fragments (Table 2) were determined from two gels at long pulse times and one gel at short pulse times (not shown). AscI cleaved the $B$. thuringiensis subsp. berliner 1715 chromosome into seven fragments ranging in size from 70 to $1790 \mathrm{~kb}$ (Fig. 1b, lane 3), whereas Sfil generated six fragments ranging from 280 to $1770 \mathrm{~kb}$ (Fig. 1b, lane 5). NotI generated 16 genomic fragments ranging from 50 to $1460 \mathrm{~kb}$ (Fig. 1b-d). At least four of the NotI fragments arose from linearized plasmids (see below) and were excluded in the estimation of chromosome size. The NotI digest of $B$. thuringiensis subsp. thuringiensis $\mathrm{HD} 2$ (Fig. 1c, lane 3) is shown for comparison and is clearly different from that of $B$. thuringiensis subsp. berliner 1715 (lane 4 ). The $B$. thuringiensis subsp. berliner 1715 chromosome size is $5.7 \mathrm{Mb}$ based on the average sum of the sizes of the restriction fragments using both standards (Table 1). Any fragments smaller than $23 \mathrm{~kb}$ may not have been detected by PFGE, but their contribution to the chromosome size would be small.

\section{Physical map of the B. thuringiensis subsp. berliner 1715 chromosome}

To determine the relative order of the restriction fragments generated by $A s c \mathrm{I}, N o t \mathrm{I}$ and SfiI, the fragments were blotted and hybridized to various probes. Enzyme digestion involved double, partial and complete digests using the three enzymes. In some experiments, a chromosomal fragment from a digest with one enzyme of the $B$. thuringiensis subsp. berliner 1715 chromosome or a $B$. cereus chromosome (ATCC 14579) was used as a linking probe to analyse the fragments generated by a second enzyme.

$m r e B$, the gene coding for a shape-determining protein (Narahara et al., 1992), was mapped to the $A s c$ I fragment A5, the NotI fragment N1 and the SfiI fragment S1 (Table 2). Hybridization to partial $A s c \mathrm{I}$ digests revealed that A4 and $A 7$ were the neighbouring fragments of $A 5$, and that A6 neighboured A7. Hybridization to partial NotI digests showed that a small NotI fragment of about $50 \mathrm{~kb}$ (N10) was the neighbouring fragment of N1. rRNA genes were mapped to $A 5$, and to the neighbouring fragment $A 4$, and hybridization with an $\mathrm{rRNA}$ probe confirmed the alignments of the fragments obtained by the $m r e B$ probe. The rRNA probe also hybridized weakly to N4 and it is possible that this NotI fragment contains one copy of the gene operon. This gene operon was mapped to the SfII fragment $\mathrm{S} 5$. Of five $B$. cereus probes also mapped to $\mathrm{N} 4$, one (Bc209) hybridized to $\$ 4$ and four (Bc52, Bc54, tcr and syn) hybridized to S6. Using these results, the three smallest SfiI fragments (S4, S6 and S5) were aligned. S1 was linked to $S 5$ by using a linking fragment probe of $290 \mathrm{~kb}$ from the B. cereus ATCC 14579 chromosome, whereas S2 was linked to S4 when N6 was used as a linking fragment probe (Table 2). The AscI site between $\mathrm{A} 1$ and $\mathrm{A} 3$ was located on the map when $\beta$-lacII and Bc45 (both mapped to $\mathrm{N} 2$ and $\mathrm{S} 2$ ) were hybridized against $A s c \mathrm{I}$ 
Table 2. Probes which hybridized to Ascl, Notl, Sfil and double-digested DNA from B. thuringiensis subsp. berliner 1715

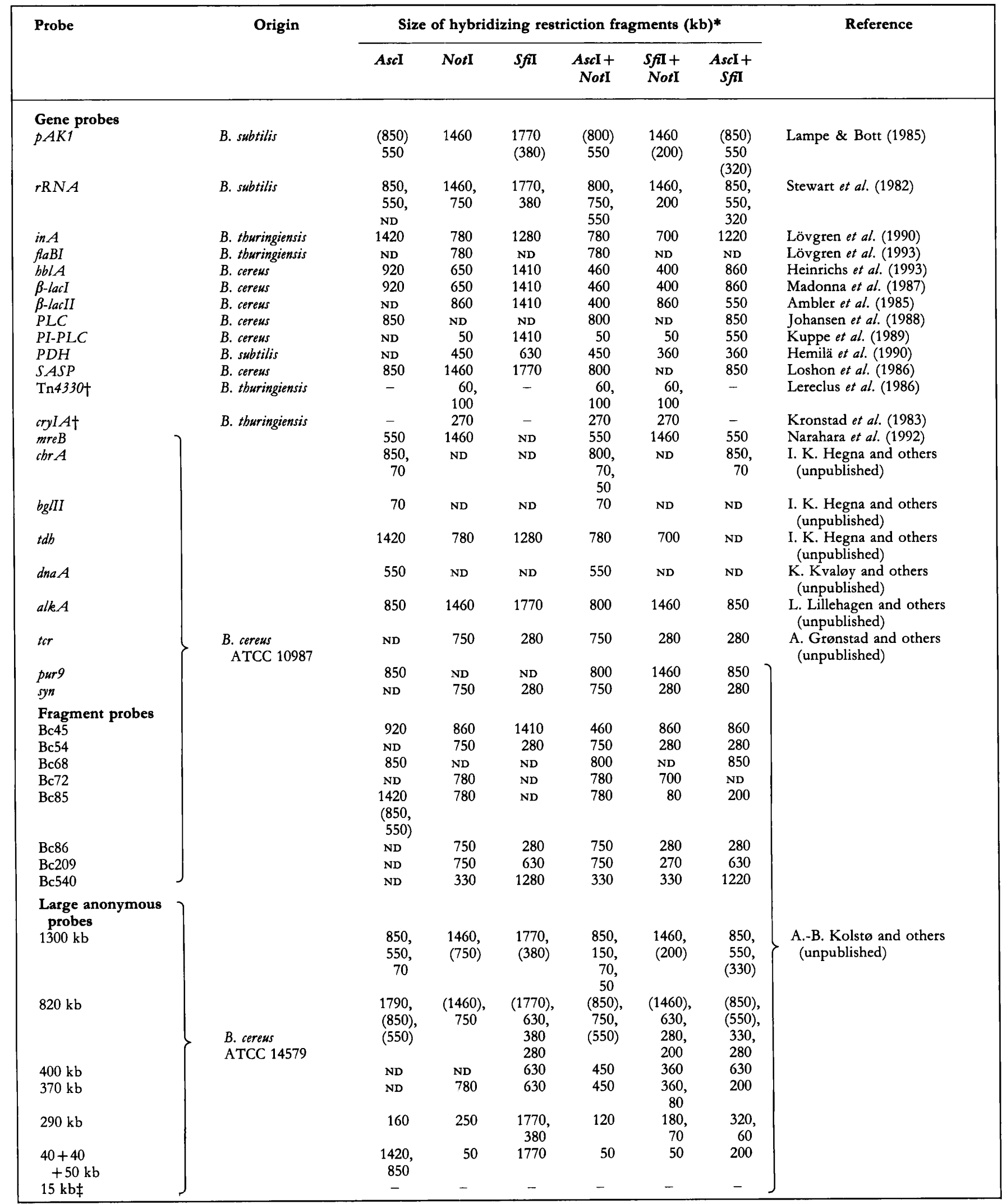

ND, Not determined; -, negative.

* Fragments in parentheses contained rRNA genes and gave weak cross-hybridization.

†On extrachromosomal DNA (see text).

$\ddagger$ The $15 \mathrm{~kb}$ fragment was extrachromosomal. 
(a)

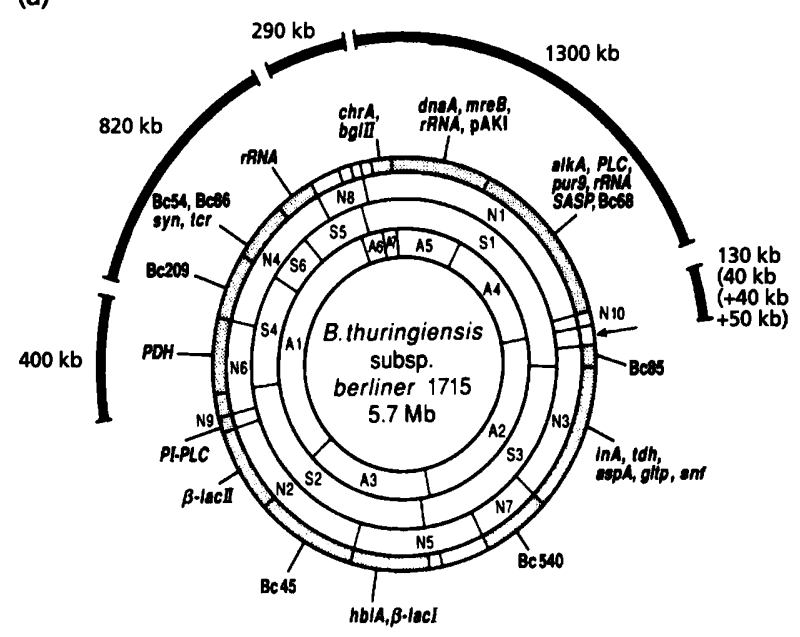

(b)

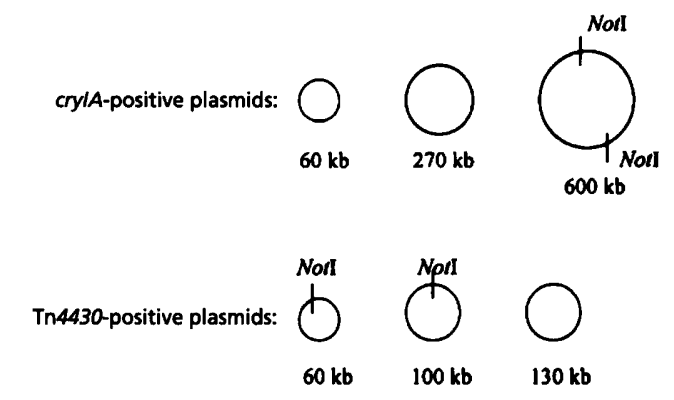

Fig. 2. (a) Physical map of $B$. thuringiensis subsp. berliner 1715 showing Ascl (inner circle), Notl (outer circle) and Sfil (middle circle) sites. The hatched circle shows restriction fragments that hybridized to various probes. The arrow indicates a region of the chromosome which contains at least two more Notl restriction sites, the positions of which have not been determined. Some of the Notl fragments of the B. cereus ATCC 14579 chromosome are drawn outside the corresponding part of the chromosome of $B$. thuringiensis subsp. berliner 1715. (b) Proposed extrachromosomal DNA elements larger than $50 \mathrm{~kb}$ in $B$. thuringiensis subsp. berliner 1715 detected by using a crylA probe and a Tn4430 probe. Tn4430 has also previously been shown to be located on the crylA-positive plasmid of $60 \mathrm{~kb}$ (see text).

and SfiI double-digested DNA. Alignment of the NotI fragments N3, N7 and N5, and linking of S2 to S3 and $\mathrm{A} 2$ to $\mathrm{A} 3$, were achieved by hybridization of $b b l A$ (mapped to $\mathrm{N} 5$ ), Bc540 (mapped to N7) and in $A$ (mapped to N3) to single and double digests using the three enzymes (Table 2 ) and to partial NotI digests. A2 was linked to fragment A4 by using a fragment probe from B. cereus ATCC 14579 consisting of three neighbouring Not I fragments of 40,40 and $50 \mathrm{~kb}$ (Table 2) (Carlson et al., 1992). Hybridization with this linking probe showed that this part of the $B$. thuringiensis subsp. berliner 1715 chromosome also contained several smaller NotI fragments, including N10, of $50 \mathrm{~kb}$. The position of N10 relative to the $A s c \mathrm{I}$ site between $\mathrm{A} 2$ and $\mathrm{A} 4$ has not been determined. This linking probe hybridized to the same $A s c \mathrm{I}$ and $S$ fiI doubledigested fragment of $200 \mathrm{~kb}$ as $\mathrm{Bc} 85$ (Table 2). Bc85 also hybridized to A2, N3 and the NotI and Sfi doubledigested fragment of $50 \mathrm{~kb}$, and by combining these results with the results obtained by the linking probe above, S1 could be aligned next to S3. The final arrangement of the AscI, NotI and SfiI restriction sites in the physical map of $B$. thuringiensis subsp. berliner 1715 is shown in Fig. 2(a). Any fragments smaller than $23 \mathrm{~kb}$ after double digestion have not been determined.

\section{Assignment of probes to the restriction fragments}

We used Southern hybridization to place 28 gene probes and anonymous probes on the restriction map (Fig. 2a) (Table 2). Most of the probes were obtained from B. cereus ATCC 10987 and B. thuringiensis, but three were from $B$. subtilis (Table 2). Hybridization with all these probes to AscI, NotI, SfiI fragments and combination thereof confirmed the order of the restriction fragments in the chromosome map (Fig. 2a).

The fragments from B. cereus ATCC 10987 have been partly or fully sequenced and contain putative genes such as $\operatorname{tcr}$ (A. Grønstad and others, unpublished), $c b r A$, bglII, $t d b$ (I. K. Hegna and others, unpublished), pur9, syn, gltp, asp $A$ (A.-B. Kolstø and others, unpublished), dna $A$ (K. Kvaløy and others, unpublished), alk $A$ (L. Lillehagen and others, unpublished) and $m r e B$ (Narahara et al., 1992). Bc85 hybridized most strongly to a $780 \mathrm{~kb}$ NotI fragment, but also weakly to other parts of the chromosome (to two $A s c \mathrm{I}$ fragments of 550 and $850 \mathrm{~kb}$ ). This anonymous probe also hybridized strongly to yeast chromosomes. $c b r A$ hybridized most strongly to A7 of $70 \mathrm{~kb}$, but also weakly to A4 of $850 \mathrm{~kb}$ (Table 2). Most of these probes were located on one half of the chromosome map. The $\operatorname{dna} A$ probe hybridized to a $550 \mathrm{~kb} A s c \mathrm{I}$ fragment (A5), indicating that the origin of replication is most likely located on this part of the chromosome. The rRNA genes were mapped to three restriction fragments (A4, A5 and S5 in Fig. 3) including the fragment containing the proposed origin region. A probe from $B$. subtilis (pAK1) covering $r e c F, g y r A$ and gyrB (Lampe \& Bott, 1985) hybridized most strongly to the fragment containing the origin region (A5), but also weakly to A4 and S5. The other half of the chromosome contained sequences which are often plasmid-encoded such as $\beta$-lacI, $\beta$-lacII, in $A$ and $b b l A$. The $b b l A$ gene (mapped to N5) codes for the B component of haemolysin $\mathrm{BL}$ which may be responsible for the diarrhoeal form of $B$. cereus food poisoning (Beecher \& Macmillan, 1990, 1991). We have previously shown that several $B$. thuringiensis strains produce enterotoxin (Carlson \& Kolstø, 1993).

A probe for an insecticidal toxin gene, $\operatorname{cry} I A$, hybridized to a NotI fragment of $270 \mathrm{~kb}$, and a probe for $\operatorname{Tn} 4430$ hybridized to two NotI fragments of $60 \mathrm{~kb}$ and $100 \mathrm{~kb}$. As discussed later, these NotI fragments were derived from extrachromosomal DNA. 

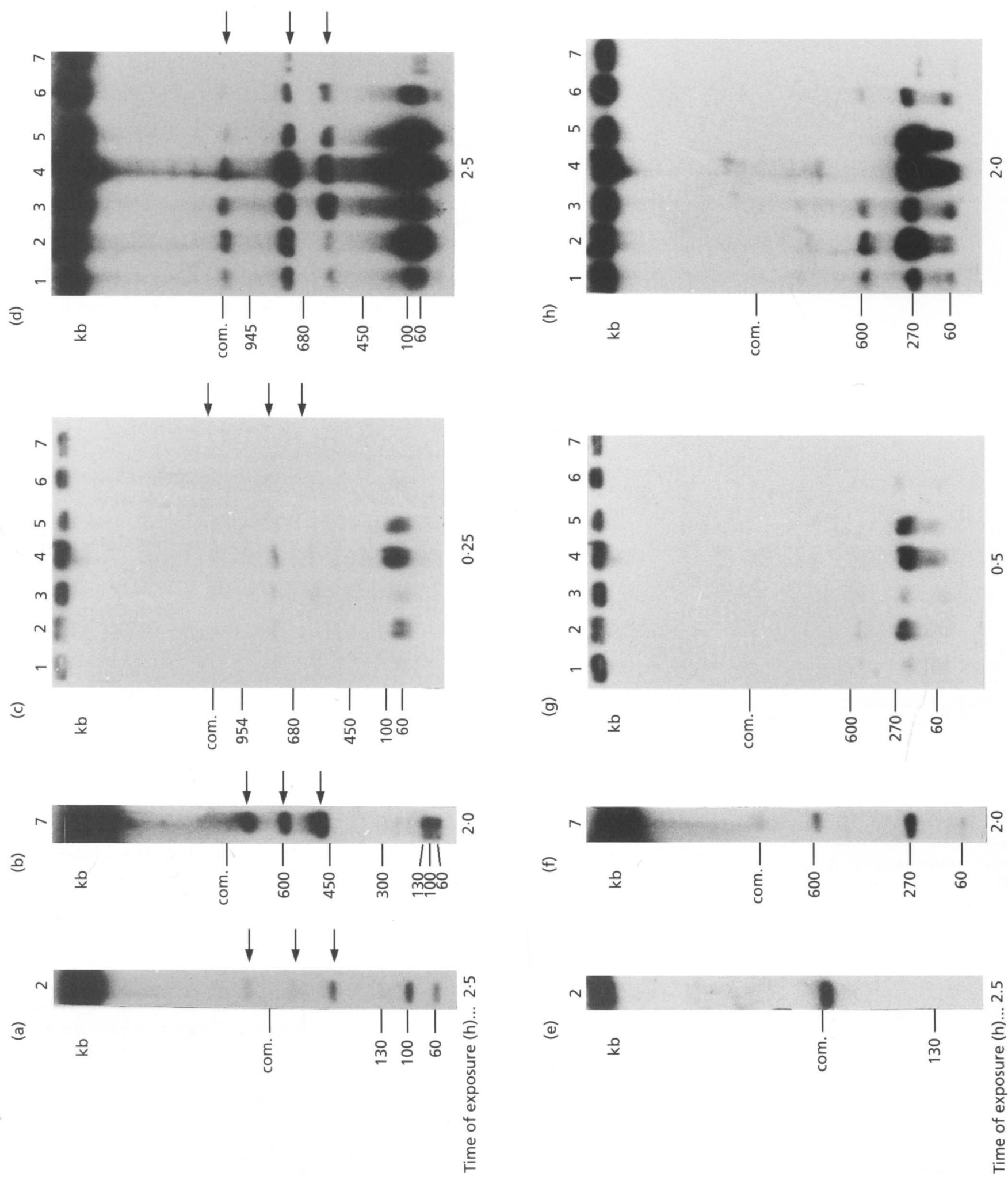


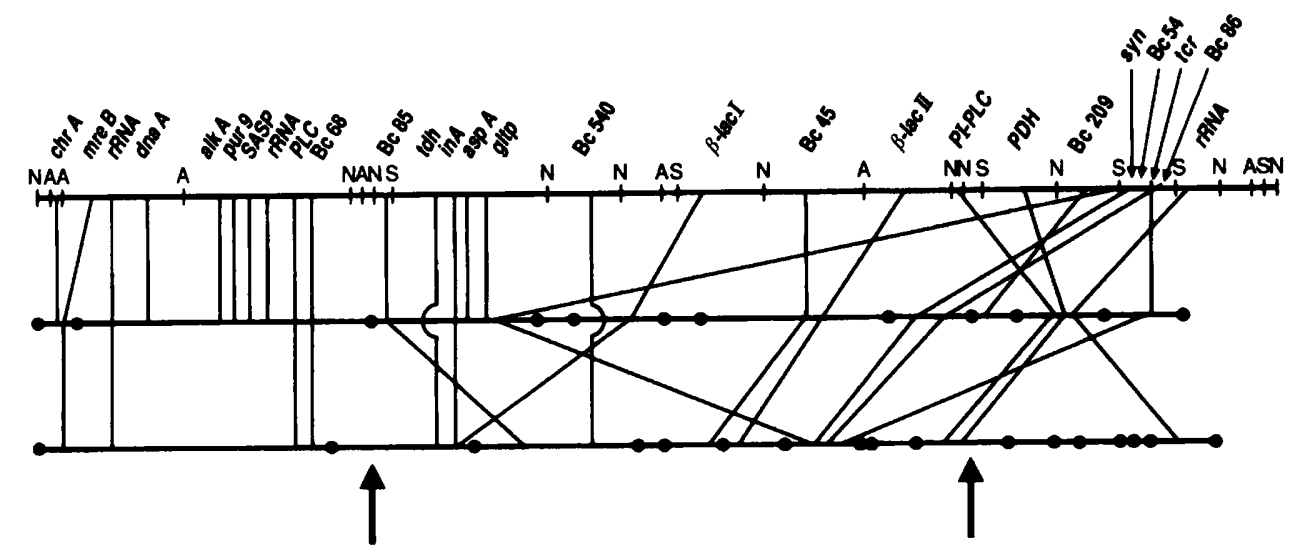

B. thuringiensis subsp. berliner 1715

B. cereus ATCC 10987

B. thuringiensis

subsp. thuringiensis HD2

Fig. 4. Comparison of the linearized chromosome maps of $B$. thuringiensis subsp. berliner $1715, B$. cereus ATCC 10987 and $B$. thuringiensis subsp. thuringiensis HD2. Each line represents the position of a probe, which within the fragment, is arbitrary. A, Ascl; N, Notl; S, Sfil.

\section{Cross-hybridization between restriction fragments from B. thuringiensis subsp. berliner 1715 and $B$. cereus type strain ATCC 14579}

Chromosomal NotI fragments from the B. cereus type strain ATCC 14579 were also used as probes in the mapping of the $B$. thuringiensis subsp. berliner 1715 chromosome (Table 2). The fragment probes used were mainly from the conserved part of the $B$. cereus chromosome surrounding the putative origin (Carlson \& Kolstø, 1994). Hybridization with these fragments gave unambiguous results, indicating conserved regions between the chromosomes. One exception was the $1300 \mathrm{~kb}$ Not I and $800 \mathrm{~kb}$ Not I fragments from $B$. cereus, both containing rRNA genes, which hybridized weakly to all fragments in B. thuringiensis containing rRNA genes (Table 2). The corresponding chromosomal regions of the two strains are shown in Fig. 2a. When a NotI fragment of $370 \mathrm{~kb}$ from the proposed variable region of $B$. cereus ATCC 14579 was used as a probe, hybridization to two different locations in the B. thuringiensis subsp. berliner 1715 chromosome (fragments N3 and S4) was obtained, indicating that these regions are less conserved than the rest of the chromosome. An extrachromosomal fragment of $15 \mathrm{~kb}$ from B. cereus ATCC 14579 did not hybridize to the $B$. thuringiensis subsp. berliner 1715 genome.

\section{Presence of extrachromosomal DNA}

The $\operatorname{Tn} 4430$ probe and a cryI $A$ probe were used in hybridization experiments against blots containing undigested DNA (Fig. 3a, b, lane 7), single digests (Fig. 3a, b, lanes 1, 2 and 3), and double digests (Fig. 3a, b, lanes 4, 5 and 6) using $A s c \mathrm{I}$, NotI and SfiI, and partial NotI digests (Fig. 3a, b, lane 2). A similar hybridization pattern in all lanes indicated that the probes were located on only extrachromosomal DNA. Tn4430 hybridized to at least six extrachromosomal bands, three of them were separated in a pulse-time-dependent manner as linear fragments of 60, 100 and $130 \mathrm{~kb}$ (Fig. 3a). These three bands probably originate from plasmids that were linearized during preparation of the DNA. The 60 and $100 \mathrm{~kb}$ bands hybridized more strongly to the $\operatorname{Tn} 4430$ probe in all Not digests (Fig. 3a, lanes 2, 4 and 5; 15 min exposure), indicating that these two plasmids contained a NotI site. The $130 \mathrm{~kb}$ extrachromosomal band hybridized weakly in all digests. The other three bands migrated in a manner independent of the pulse time as shown in Fig. 3(a) where DNA is separated at both $6 \mathrm{~s}$ pulse time and $50 \mathrm{~s}$ pulse time for $20 \mathrm{~h}$. These results suggest that these bands correspond to smaller supercoiled plasmids (Hightower \& Santi, 1989) which is consistent with the presence of several smaller plasmids in $B$. thuringiensis subsp. berliner 1715 (Klier et al., 1982; Lereclus et al., 1988).

cryI $A$ hybridized strongly to three extrachromosomal bands of about 60,270 and $600 \mathrm{~kb}$ (Fig. 3b). All three bands were separated in a pulse-time-dependent manner indicating that they were linear. However, in a complete NotI digest (Fig. 3b, lanes 4 and 5) the $600 \mathrm{~kb}$ band disappeared and the cryI $A$ probe hybridized strongly to a $270 \mathrm{~kb}$ NotI fragment. When genomic DNA was partially digested with NotI (Fig. 3b, lane 2) the $600 \mathrm{~kb}$ was still present, indicating that the $270 \mathrm{~kb}$ NotI fragment originated from the $600 \mathrm{~kb}$ plasmid. The rest of the

Fig. 3. DNA from B. thuringiensis subsp. berliner 1715 digested with Ascl, Notl or Sfil, or combinations thereof, and separated by three different pulse regimes [ $4 \mathrm{~s}$ for the first $10 \mathrm{~min}$ at $170 \mathrm{~mA}$, and then $6 \mathrm{~s}$ pulses for $20 \mathrm{~h} \mathrm{(a,e),30 \textrm {s }}$ pulses for $18 \mathrm{~h}(\mathrm{~b}, \mathrm{f})$ or $50 \mathrm{~s}$ pulses for $20 \mathrm{~h}(\mathrm{c}, \mathrm{d}, \mathrm{g}, \mathrm{h}), 150 \mathrm{~mA}, 15^{\circ} \mathrm{C}$ (Beckman)]. DNA was then blotted onto membranes and hybridized with the Tn4430 probe $(a-d)$ or the crylA probe $(e-h)$. The autoradiograms were exposed for the times indicated. Lanes: 1, Ascl digest; 2, Notl partial digest; 3, Sfil digest; 4, Ascl and Notl digest; 5, Notl and Sfil digest; 6, Ascl and Sfil digest; 7, undigested (less DNA was loaded). The sizes of some of the linear fragments that hybridized and yeast chromosomes are indicated on the left. Com. indicates the compression region (see legend to Fig. 1). The arrows indicate extrachromosomal DNA that hybridized to the Tn 4430 probe and might be supercoiled molecules. 
plasmid may correspond to the NotI fragment of about $300 \mathrm{~kb}$ and perhaps one or two of the smaller NotI fragments that have not yet been placed (Table 1, Fig. 1d). Thus, $B$. thuringiensis subsp. berliner 1715 contained several large plasmids that were linearized by NotI. These Not $\mathrm{I}$ fragments were not derived from the chromosome since the cryI $A$ and $\operatorname{Tn} 4430$ probe did not hybridize to any $A s c \mathrm{I}$ and SfiI chromosomal fragments, and these NotI fragments were not connected with the chromosomal fragments in any partial Not I digests. It has been reported that the crystal protein gene is located on the chromosome as well as on plasmids in B. thuringiensis subsp. berliner 1715 (Klier et al., 1982), while other investigators have only identified extrachromosomal cry genes in this strain (Kronstad et al., 1983). It is possible that the cryI $A$ gene previously identified as chromosomal in location may have originated from a very large plasmid. In our previous mapping study of a $B$. cereus strain (Carlson \& Kolstø, 1994), we found that the large extrachromosomal DNA elements were isolated together with the chromosomal DNA by a caesium chloride gradient (A.-B. Kolstø, unpublished). A plasmid of $64 \mathrm{~kb}$ containing both $\operatorname{cryI} A$ and Tn4430 as well as IS elements is present in the $B$. thuringiensis subsp. berliner 1715 strain (Menou et al., 1990). It is likely that this plasmid corresponds to the $\operatorname{cry} I A$ positive plasmid without any NotI site with the apparent size of $60 \mathrm{~kb}$. However, the presence of $\operatorname{Tn} 4430$ on this plasmid was not easily verified in our experiments because Tn4430 also hybridized strongly to another $60 \mathrm{~kb}$ Not $\mathrm{I}$ fragment. Fig. 2b illustrates the large extrachromosomal DNA elements that were detected by PFGE analysis and hybridization with the $\operatorname{cryI} A$ and the Tn4430 probe. The sum of the six plasmids or the extrachromosomal DNA was $1.2 \mathrm{Mb}$ indicating that the genome size was at least $6.9 \mathrm{Mb}$.

In the hybridization experiments we also used probes containing B. thuringiensis plasmids of 9.2 and $10.6 \mathrm{~kb}$, and about half of a third plasmid of $8.2 \mathrm{~kb}$ (Mahillon et al., 1988). Except for the $9 \cdot 2 \mathrm{~kb}$ plasmid, which also contained the Tn4430 element, these probes hybridized to yet additional extrachromosomal DNA elements that had not been identified using the Tn 4430 probe or the $\operatorname{cryI} A$ probe (data not shown). We also used a probe from the replication origin of a $B$. thuringiensis plasmid (ori44) (Baum \& Gilbert, 1991). The ori44 probe hybridized to one of the $60 \mathrm{~kb}$ elements that was positive for the $\operatorname{Tn} 4430$ probe and the cryI $A$ probe (Fig. $2 \mathrm{~b}$ ). These results confirm that a large amount of extrachromosomal DNA is present in the $B$. thuringiensis subsp. berliner 1715 strain.

The $5.7 \mathrm{Mb}$ chromosome of $B$. thuringiensis subsp. berliner 1715 is about the same size as the $B$. thuringiensis subsp. thuringiensis HD2 chromosome (Carlson \& Kolstø, 1993) and the largest $B$. cereus chromosomes $(5.3 \mathrm{Mb}-6.3 \mathrm{Mb}$; Carlson et al., 1992; Carlson \& Kolstø, 1994; Kolstø et al., 1990). Both B. thuringiensis strains belong to serotype 1 and have previously been analysed by multilocus enzyme electrophoresis. B. thuringiensis subsp. thuringiensis HD2 clustered together with $B$. cereus strains, including $B$. cereus ATCC 10987 (Carlson et al., 1994), whereas B. thuringiensis subsp. berliner 1715 clustered with several $B$. thuringiensis strains (D. Caugant, unpublished). Fig. 4 shows the positions of the probes within the linearized AscI, NotI and Sfi map of B. thuringiensis subsp. berliner 1715 compared to that of the NotI maps of $B$. thuringiensis subsp. thuringiensis HD2 and B. cereus ATCC 10987. Although the genomic fingerprint patterns of the two $B$. thuringiensis strains are different (Fig. 1c, lanes 3 and 4), the genetic organization appears similar in one half of the chromosomes (to the left in the figure). This corresponds to the conserved region of the $B$. thuringiensis subsp. berliner 1715 and B. cereus type strain ATCC 14579 chromosomes (Fig. 2a). The chromosomal regions to the right in Fig. 4 are more variable. The two arrows indicate the borders between the conserved and variable parts previously identified in the B. cereus ATCC 10987 chromosome (Carlson \& Kolstø, 1994). These borders were clearly less well defined when comparing the probe positions within the three maps. However, the genetic organization within the chromosome map of $B$. thuringiensis subsp. berliner 1715 was as similar to $B$. thuringiensis subsp. thuringiensis $\mathrm{HD} 2$ (also serotype 1) as the latter was to the larger B. cereus strains previously mapped (Carlson \& Kolstø, 1993). The results are consistent with our proposition that the large chromosomes of $B$. cereus $/ B$. thuringiensis consist of a conserved region containing the origin and rRNA genes, and a more variable region which contains genes which are often plasmid-encoded (Carlson \& Kolstø, 1994).

When probes for the genes previously mapped by transduction (Heierson et al., 1983; Lecadet et al., 1980) are available, the physical map could be combined with the genetic map (Vary, 1993).

\section{ACKNOWLEDGEMENTS}

This work was supported by grants to A.-B.K. from the Norwegian Research Council and from the Norwegian Directory for the preservation of nature. We thank Drs Lövgren, Mahillon and Macmillan for providing probes, and Serena Pringle for reading the manuscript.

\section{REFERENCES}

Allardet-Servent, A., Michaux-Charachon, S., Jumas-Bilak, E., Karayan, L. \& Ramuz, M. (1993). Presence of one linear and one circular chromosome in the Agrobacterium tumefaciens C58 genome. $J$ Bacteriol 175, 7869-7874.

Ambler, R. P., Daniel, M., Fleming, J., Hermoso, J., Pang, C. \& Waldey, S. G. (1985). The amino acid sequence of the zincrequiring $\beta$-lactamase II from the bacterium Bacillus cereus 569 . FEBS Lett 185, 207-211.

Aronson, A. I. (1993). Insecticidal toxins. In Bacillus subtilis and Other Gram-Positive Bacteria: Biochemistry, Pbysiology and Molecular Genetics, pp. 953-963. Edited by A. L. Sonenshein, J. A. Hoch \& R. Losick. Washington, DC: American Society for Microbiology. Baum, J. A. \& Gilbert, M. P. (1991). Characterization and com- 
parative sequence analysis of replication origins from three large Bacillus thuringiensis plasmids. J Bacteriol 173, 5280-5289.

Beecher, D. J. \& Macmillan, J. D. (1990). A novel biocomponent hemolysin from Bacillus cereus. Infect Immun 58, 2220-2227.

Beecher, D. J. \& Macmillan, J. D. (1991). Characterization of the components of hemolysin BL from Bacillus cereus. Infect Immun 59, 1778-1784.

Beverley, S. M. (1988). Characterization of the 'unusual' mobility of large circular DNAs in pulsed field-gradient electrophoresis. Nucleic Acids Res 16, 925-939.

Carlson, C. R. \& Kolstø, A.-B. (1993). A complete physical map of a Bacillus thuringiensis chromosome. J Bacteriol 175, 1053-1060.

Carlson, C. R. \& Kolstø, A.-B. (1994). A small (2.4 Mb) Bacillus cereus chromosome corresponds to a conserved region of a larger $(5.3 \mathrm{Mb})$ Bacillus cereus chromosome. Mol Microbiol 13, 161-169.

Carlson, C. R., Grønstad, A. \& Kolstø, A.-B. (1992). Physical maps of the genomes of three Bacillus cereus strains. J Bacteriol 174, 3750-3756.

Carlson, C. R., Caugant, D. A. \& Kolstø, A.-B. (1994). Genotypic diversity among Bacillus cereus and Bacillus tburingiensis. Appl Environ Microbiol 60, 1719-1725.

Carlton, B. C. \& Gonzales, J. M., Jr (1985). Plasmids and deltaendotoxin production in different subspecies of Bacillus thuringiensis. In Molecular Biology of Microbial Differentiation, pp. 246-252. Edited by J. A. Hoch \& P. Setlow. Washington, DC: American Society for Microbiology.

Feinberg, A. P. \& Vogelstein, B. (1983). A technique for radiolabelling DNA restriction endonuclease fragments to high specific activity. Anal Biochem 132, 6-13.

Feinberg, A. P. \& Vogelstein, B. (1984). Addendum. Anal Biochem 137, 266-267.

Gordon, R. E., Haynes, W. C. \& Pang, C. H.-N. (1973). The genus Bacillus. Agriculture Handbook no. 427. Washington, DC: United States Department of Agriculture.

Heierson, A., Landén, R. \& Boman, H. G. (1983). Transductional mapping of nine linked genes in Bacillus thuringiensis. Mol Gen Genet 192, 118-123.

Heinrichs, J. H., Beecher, D. J., Macmillan, J. D. \& Zilinskas, B. A. (1993). Molecular cloning and characterization of the $b b l A$ gene encoding the $\mathrm{B}$ component of hemolysin $\mathrm{BL}$ from Bacillus cereus. J Bacteriol 175, 6760-6766.

Hemila, H., Palva, A., Paulin, L., Arvidson, S. \& Palva, I. (1990). Secretory S complex of Bacillus subtilis: sequence analysis and identity to pyruvate dehydrogenase. J Bacteriol 172, 5052-5063.

Hightower, R. C. \& Santi, D. V. (1989). Migration properties of circular DNAs using orthogonal-field-alternation gel electrophoresis. Electrophoresis 10, 283-290.

Hofte, H. \& Whiteley, H. R. (1989). Insecticidal crystal proteins of Bacillus thuringiensis. Microbiol Rev 53, 242-255.

Johansen, T., Holm, T., Guddal, P. H., Sletten, K., Haugli, F. B. \& Little, C. (1988). Cloning and sequencing of the gene encoding the phosphatidylcholine-preferring phospholipase $C$ of Bacillus cereus. Gene 65, 293-304.

Klier, A., Fargette, F., Ribier, J. \& Rapoport, G. (1982). Cloning and expression of the crystal genes from Bacillus thuringiensis strain berliner 1715. EMBO J 1, 791-799.

Kolstø, A.-B., Grønstad, A. \& Oppegaard, H. (1990). Physical map of the Bacillus cereus chromosome. J Bacteriol 172, 3821-3825.

Kronstad, J. W., Schnepf, H. E. \& Whiteley, H. R. (1983). Diversity of locations for Bacillus thuringiensis crystal protein genes. $J$ Bacteriol 154, 419-428.

Kuppe, A., Evans, L. M., McMillen, D. A. \& Griffith, O. H. (1989). Phosphatidylinositol-specific phospholipase $C$ of Bacillus cereus: cloning, sequencing and relationship to other phospholipases. $J$ Bacteriol 171, 6077-6083.

Lampe, M. F. \& Bott, K. F. (1985). Genetic and physical organization of the cloned gyr $A$ and gyrB genes of Bacillus subtilis. J Bacteriol 162, 78-84.

Lecadet, M.-M., Blondel, M.-O. \& Ribier, J. (1980). Generalized transduction in Bacillus thuringiensis var. berliner 1715 using bacteriophage CP-54Ber. J Gen Microbiol 121, 203-212.

Lereclus, D., Mahillon, J., Menou, G. \& Lecadet, M.-M. (1986). Identification of $\operatorname{Tn} 4430$, a transposon of Bacillus thuringiensis functional in Escherichia coli. Mol Gen Genet 204, 52-57.

Lereclus, D., Gou, S., Sanchis, V. \& Lecadet, M.-M. (1988). Characterization of two Bacillus thuringiensis plasmids whose replication is thermosensitive in B. subtilis. FEMS Microbiol Lett 49, $417-422$.

Loshon, C. A., Fliss, E. R., Setlow, B., Foerster, H. F. \& Setlow, P. (1986). Cloning and nucleotide sequencing of genes for small acidsoluble spore proteins of Bacillus cereus, Bacillus stearothermophilus and Thermoactinomyces thalpophilus. J Bacteriol 167, 168-173.

Lövgren, A., Zhang, M.-Y., Engström, Å., Dalhammer, G. \& Landén, R. (1990). Molecular characterization of immune inhibitor A, a secreted virulence protease from Bacillus thuringiensis. Mol Microbiol 4, 2137-2146.

Lövgren, A., Zhang, M.-Y., Engström, Å. \& Landén, R. (1993). Identification of two expressed flagellin genes in the insect pathogen Bacillus thuringiensis subsp. alesti. J Gen Microbiol 139, 21-30.

Madonna, M. J., Zhu, Y. F. \& Lampen, J. O. (1987). Nucleotide sequence of the beta-lactamase I gene of Bacillus cereus strains $569 / \mathrm{H}$ and 5/B. Nucleic Acids Res 15, 1877.

Mahillon, J., Seurinck, J., van Rompuy, L., Delcour, J. \& Zabeau, M. (1985). Nucleotide sequence and structural organization of an insertion sequence element (IS231) from Bacillus thuringiensis strain berliner 1715. EMBO J 4, 3895-3899.

Mahillon, J., Hespel, F., Pierssens, A. M. \& Delcour, J. (1988). Cloning and partial characterization of three small cryptic plasmids from Bacillus thuringiensis. Plasmid 19, 169-173.

Menou, G., Mahillon, J., Lecadet, M.-M. \& Lereclus, D. (1990). Structural and genetic organization of IS232, a new insertion sequence of Bacillus thuringiensis. J Bacteriol 172, 6689-6696.

Narahara, A., Naterstad, K., Kristensen, T., Lopez, R., Bork, P. \& Kolstø, A.-B. (1992). Cloning of a gene from Bacillus cereus with homology to the mreB gene from Escherichia coli. Gene 122, 181-185.

Schwartz, D. C. \& Cantor, C. R. (1984). Separation of yeast chromosome-sized DNAs by pulsed field gradient gel electrophoresis. Cell 37, 67-75.

Smith, C. L. \& Condemine, G. (1990). New approaches for physical mapping of small genomes. J Bacteriol 172, 1167-1172.

Smith, C. L., Kelo, S. R. \& Cantor, C. R. (1988). Pulsed field gel electrophoresis and the technology of large DNA molecules. In Genome Analysis. A Practical Approach, pp. 41-72. Edited by K. E. Davies. Oxford: IRL Press.

Smith, N. R., Gordon, R. E. \& Clark, F. E. (1952). Aerobic Sporeforming Bacteria, pp. 56-67. Washington, DC: United States Department of Agriculture.

Sobral, B. W., Honeycutt, R. J., Atherly, A. G. \& McClelland, M. (1991). Electrophoretic separation of the three Rbizobium meliloti replicons. J Bacteriol 173, 5173-5180. 
Stewart, G. C., Wilson, F. E. \& Bott, K. F. (1982). Detailed physical mapping of the ribosomal RNA genes of Bacillus subtilis. Gene 19, 153-162.

Vary, P. S. (1993). The genetic map of Bacillus megaterium. In Bacillus subtilis and Other Gram-Positive Bacteria: Biochemistry, Physiology and Molecular Genetics, pp. 475-481. Edited by A. L. Sonenshein, J. A.
Hoch and R. Losick. Washington, DC: American Society for Microbiology.

Received 9 January 1996; revised 12 February 1996; accepted 15 February 1996. 